\title{
SCANNING ELECTRON MICROSCOPY OF LISTERIA MONOCYTOGENES BIOFILMS ON STAINLESS STEEL SURFACES
}

MILANOV DUBRAVKA*, AŠANIN RUŽICA**, VIDIĆ BRANKA*, KRNJAIĆ D**, PETROVIĆ JELENA* and SAVIĆ SARA*

\footnotetext{
*Scientific Veterinary Institute "Novi Sad", Novi Sad, Serbia

**University of Belgrade, Faculty of Veterinary Medicine, Serbia

(Received $9^{\text {th }}$ January 2009)
}

Listeria monocytogenes is the causative agent of numerous epidemics and sporadic cases of illness in humans. Food is the principal route of infection. Raw materials of animal and vegetable origin are the potential sources of contamination with this bacterium, particularly the foodstuff undergoing minimal processing procedures. However, in the recent years, emphasis has been increasingly laid on the importance of post-processing contamination occurring through the contact of products with contaminated surfaces in food-processing plants, where this bacterium can persist for months, even for years, as a biofilm. Although it appears to be widely accepted that $L$. monocytogenes forms biofilms on food-processing surfaces, there has been very little direct microscopical evidence to support this.

In this study we investigated the ability of biofilm formation in 14 strains of Listeria monocytogenes of different origin. The biofilms were formed on stainless steel surfaces during 7 days of incubation in a tryptone soy broth supplemented with $0.6 \%$ yeast extract (TSB-YE) at a temperature of $25^{\circ} \mathrm{C}$. The developed structures were examined using scanning electron microscopy.

Our results revealed significant differences among tested Listeria monocytogenes strains in terms of their ability to form a biofilm in given experimental conditions. Seven of 14 investigated strains of Listeria monocytogenes did not form a biofilm, and only individual bacterial cells were distributed over the stainless steel surface. The strains classified as biofilm producers formed structures of different appearances, from a uniform, confluent monolayer of bacterial cells to individual large, three-dimensional cell aggregates. All strains proved weak producers of extracellular polymeric substance.

Key words: Listeria monocytogenes, scanning electron microscopy, biofilm, stainless steel 


\section{INTRODUCTION}

Listeria monocytogenes is a human pathogen that is responsible for serious infections in immunocompromised individuals and pregnant women. Ingestion of usually heavily contaminated foods is the principal route of infection. The mortality rate in systemic listeriosis has been estimated as between $20 \%$ and $40 \%$ (McLauchlin et al., 2004). Based on the Centers for Disease Control and Prevention's recent estimations, the annual incidence of death caused by listeriosis is about eight times greater than that caused by Escherichia coli O157:H7 (Mead et al., 1999).

Several studies have focused on elucidating the sources and contamination routes of $L$. monocytogenes in food-processing environments. These studies concluded that raw materials were not a major source of contamination, but that contamination occurred during processing and that the food-processing equipment can act as a reservoir of $L$. monocytogenes (Möretrö and Langsrud, 2004; Vogel et al., 2001). Listeria monocytogenes can be found on and in various equipment and in the working environment such as gaskets, conveyor belts, slicing, dicing and packaging machines, containers, knives, tables, drains, floors and walls (Nelson, 1990). Certain clones of L. monocytogenes can persist in the food processing environments for years. The possibility that these persistent strains could be specifically adapted to survive in a biofilm is a potential explanation. Biofilm is a microbially derived sessile community characterized by cells that are irreversibly attached to a substratum or interface or to each other, embedded in a matrix of extracellular polymeric substances that they have produced, and which exhibit an altered phenotype with respect to growth rate and gene transcription (Donlan and Costerton, 2002). Biofilms have the potential to act as a chronic source of microbial contamination, which may compromise food quality and represent a significant health hazard.

Although it appears to be widely accepted that $L$. monocytogenes forms biofilms on food-processing surfaces, there has been very little direct microscopical evidence to support this (Kalmokoff et al., 2001). Scanning electron micrographs demonstrating the presence of individual cells on various surfaces have been reported (Herald and Zottola, 1988; Mafu et al., 1990; Blackman and Frank, 1996). Contrary to that, Chavant et al. (2002) and Borucki et al. (2003) described the biofilm of some strains of $L$. monocytogenes as a dense threedimensional cellular network with channels and pores between cell aggregates. Marsh et al. (2003) correlated the appearance of the biofilm of $L$. monocytogenes strains with a "honeycomb" pattern. By applying a confocal scanning laser microscopy Chae and Schraft (2000) established a double-layer structure of a $L$. monocytogenes biofilm. The described appearance of the biofilm of $L$. monocytogenes departs from widely accepted "mushroom-shaped" structure, and numerous determining factors are related to experimental conditions, strain characteristics, substrate type, incubation period and temperature, as well as the composition of the nutritive medium. 
Acta Veterinaria (Beograd), Vol. 59. No. 4, 423-435, 2009.

In this study we investigated the ability of various strains of $L$. monocytogenes to form biofilms on stainless steel surfaces, and the appearance of formed structures was examined by the use of scanning electronic microscopy.

\section{MATERIALS AND METHODS}

Bacterial strains

The investigation was conducted using 14 strains of Listeria monocytogenes. The strains used in this research were isolated from animals (8 strains), food (4 strains) and feed (1 strain); while a human strain (ATCC 19115) was used as the referent strain. Bacterial strains were identified according to their cultural and tinctorial features, applying catalase, oxidase and CAMP test. Biochemical characteristics were determined applying MICROBACT ${ }^{\mathrm{TM}}$ identification system 12L (Oxoid, Basingstoke, UK). Serological typing of the strains was performed using specific sera for $\mathrm{O}$ and $\mathrm{H}$ antigens for Listeria species. (Listeria antisera, DENKA SEIKEN, UK). L. monocytogenes strain origin and their serological types are displayed in Table 1.

Table 1. Listeria monocytogenes strains used in this study

\begin{tabular}{|c|c|c|}
\hline Isolate & Source & Serotype \\
\hline \hline $785 / 05$ & brain tissue of sheep & $1 / 2 \mathrm{a}$ \\
\hline $593 / 05$ & brain tissue of sheep & $4 \mathrm{~b}$ \\
\hline $748 / 05$ & feed (hay) & $3 \mathrm{a}$ \\
\hline $1915 / 04$ & brain tissue of sheep & $4 \mathrm{~b}$ \\
\hline $021 / 04$ & uterus of cows & $3 \mathrm{a}$ \\
\hline A & uterus of cows & $3 \mathrm{a}$ \\
\hline C & aborted fetuses of cows & $3 \mathrm{a}$ \\
\hline F & uterus of cows & $1 / 2 \mathrm{a}$ \\
\hline 16 & food (smoked herring) & $4 \mathrm{~b}$ \\
\hline 154 & food (frozen salmon) & $1 / 2 \mathrm{a}$ \\
\hline K & rabbit & $4 \mathrm{~b}$ \\
\hline 221 & food (smoked salmon) & $1 / 2 \mathrm{a}$ \\
\hline 808 & food (frozen hake) & $1 / 2 \mathrm{~b}$ \\
\hline ATCC 19115 & human isolate (control strain) & $4 \mathrm{~b}$ \\
\hline
\end{tabular}

Preparation of bacterial suspensions

All strains of $L$. monocytogenes were cultured in a blood agar with $5 \%$ sheep blood and incubated at $37^{\circ} \mathrm{C}$ during $24 \mathrm{~h}$. Three to four isolated colonies grown on blood agar were inoculated in $3 \mathrm{~mL}$ of tryptone soy broth enriched with $0.6 \%$ yeast 
extract (TSB-YE) and incubated for $24 \mathrm{~h}$ at $25^{\circ} \mathrm{C}$. After incubation the suspensions were homogenized in the vortex and diluted to 1:40 in a fresh TSB-YE.

The density of the inocula used for biofilm formation was determined by spectrophotometry (UV-VIS spectrophotometer - Anthelie advanced, Secomam) and standard plate count method from a series of ten-fold dilutions. Inoculum density was $\mathrm{OD}_{600}=0.098( \pm 0.015)$, i.e. $2-15 \times 10^{7} \mathrm{cfu} / \mathrm{mL}$.

\section{Biofilm formation}

Stainless steel coupons sized $1 \mathrm{~cm} \times 1 \mathrm{~cm} \times 0,2 \mathrm{~cm}$ were used as a substrate for biofilm formation. The coupons were boiled for $5 \mathrm{~min}$ in a detergent solution and then rinsed five times in distilled water to remove any residual detergent. The coupons were stored in $100 \%$ ethanol and sterilized by flaming prior testing. Coupons were then placed into separate wells of a sterile polystyrene 12-well plate (Nunc, Rosklide, Denmark).

Aliquots of suspension $100 \mu \mathrm{L}$ were inoculated onto the stainless steel coupon surface and incubated at $25^{\circ} \mathrm{C}$ for $3 \mathrm{~h}$ to allow adhesion to occur. After a $3 \mathrm{~h}$ incubation, the non-adherent bacteria were removed by pippeting and washed with $3 \mathrm{~mL}$ of sterile saline. Aliquots of $2 \mathrm{~mL}$ of sterile TSB-YE were inoculated into each well. Coupons were incubated over 7 days at $25^{\circ} \mathrm{C}$ and washed at 2-days intervals, and wells were inoculated with $2 \mathrm{~mL}$ of fresh TSB-YE.

Scanning electron microscopic (SEM) analysis of biofilm on stainless steel

After 7 days of incubation the coupons were removed from the well and washed by mild pipetting with $3 \mathrm{~mL}$ of sterile saline to remove the medium and non-adhered cells. The coupons were then fixed overnight at $5^{\circ} \mathrm{C}$ in $4 \%$ formaldehyde, double-washed in sterile distilled water and were dehydrated in serial dilutions of $30,50,60,70,90 \%$ ethanol for 5 min each, followed by three 10 min rinses in $100 \%$ ethanol. Air-dried preparations were immediately sputtercoated with gold (Sputer Coater SCD 005, BALTEC SCAN, WD $=50 \mathrm{~mm}, 90 \mathrm{~s}$, $30 \mathrm{~mA}$ ) and examined using scanning electron microscope JMS SEM 6460 LV, (acceleration voltage $25 \mathrm{KV}$, at WD 20 to $8 \mathrm{~mm}$ ).

\section{RESULTS AND DISCUSSION}

The results of scanning electron microscopy are displayed in micrographs, and for most strains the magnification was as low as 2000 or 5000. Lower magnification enables an insight in the coating rate of the coupon surface, i.e. ability of the examined strain to colonize the surface of stainless steel. For particular bacterial strains the details are displayed at magnifications 20000 45000.

Seven of 14 tested strains of $L$. monocytogenes did not form the biofilm in given conditions, but adhered to the surface as isolated cells distributed over the stainless steel surface (Fig.1.A-H). Similar results were reported by Kalmokoff et al. (2001). Using the scanning electron microscopy these authors established that 35 of the total of 36 investigated strains of $L$. monocytogenes did not form the biofilm and only individual bacterial cells adsorbed to the stainless steel surface. 
Acta Veterinaria (Beograd), Vol. 59. No. 4, 423-435, 2009.

Milanov Dubravka et al.: Scanning electron microscopy of

Listeria monocytogenes biofilms on stainless steel surfaces

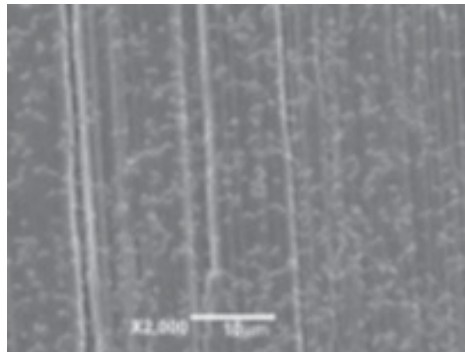

A. Strain785 / 05 (x 2000)

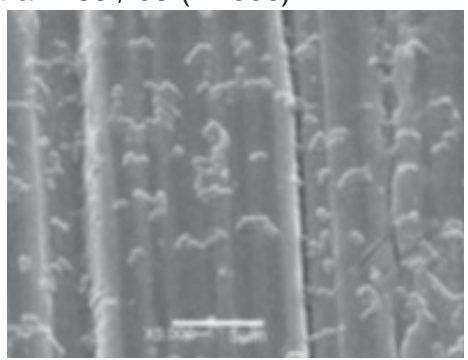

C. Strain $021 / 04$ (x 5 000)

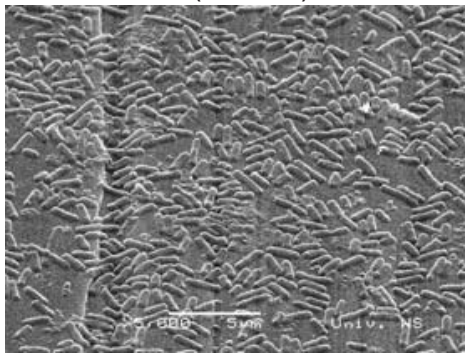

E. Strain 221 (x 5 000)

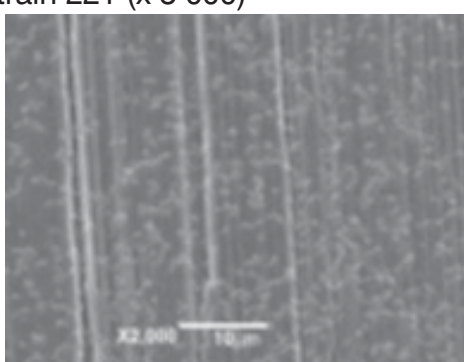

G. Strain K (x 2 000)

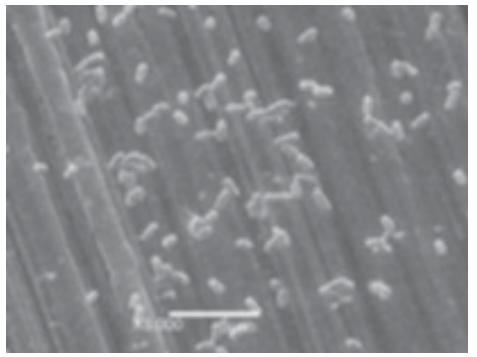

B. Strain 748 / 05 (x 5 000)

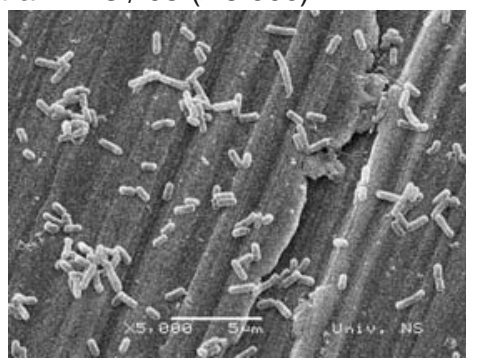

D. Strain 808 (x 5 000)

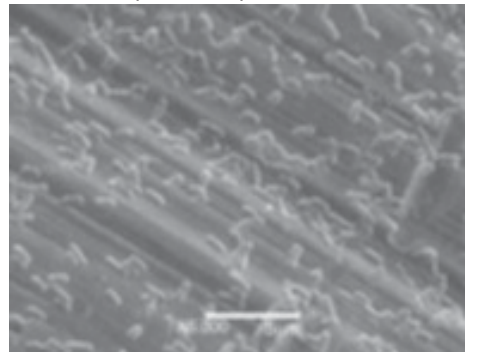

F. Strain A (x 5000$)$

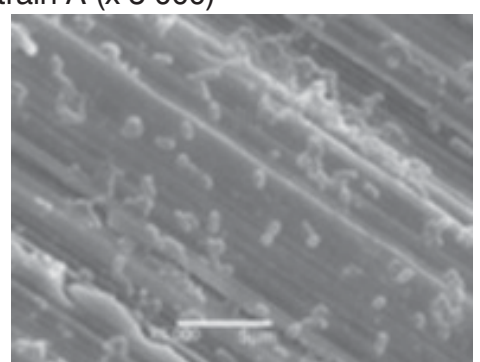

H. Strain ATCC 19115 (x 5 000)

Figure 1. SEM images - strains of Listeria monocytogenes that did not form biofilms on stainless steel for 7 days of incubation in TSB at $25^{\circ} \mathrm{C}$. Bars $5 \mu \mathrm{m}$ (magnification 5 000); bars $10 \mu \mathrm{m}$ (magnification 2000 ) 
Only one strain (serotype $4 \mathrm{~b}$ ) originating from foodstuff exhibited the ability of forming microcolonies and larger cells aggregates, i.e. a "rudimentary biofilm". In this experiment the formation of discrete cell aggregates was observed along the cracks in the stainless steel in the control strain ATCC 19115 (Fig.1.H), and to somewhat greater extent in the strain 1915/04 (Fig.2.A). Blackman and Frank (1996) also documented the formation of microcolonies by some strains of $L$. monocytogenes following long-term incubation with multiple transfers of the test surfaces into the fresh nutritive medium.

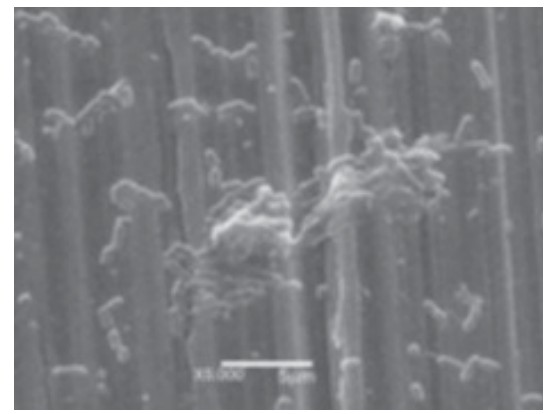

A. Strain 1915 / 04 (x 5 000)

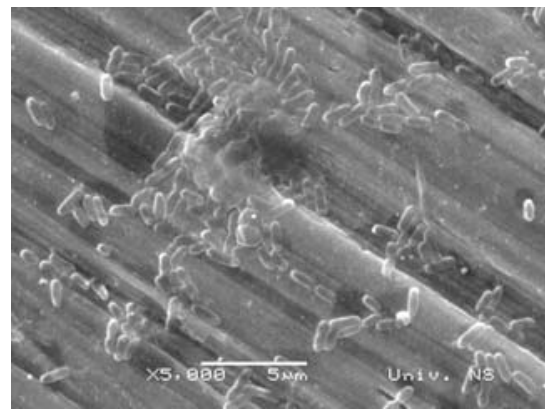

C. Strain 593 / 05 (x 5 000)

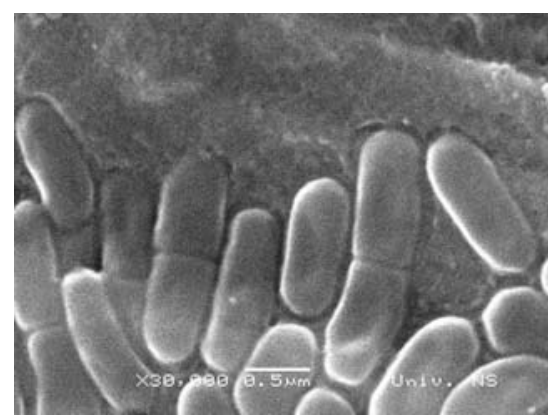

E. Strain 593 / 05 (x 30 000)

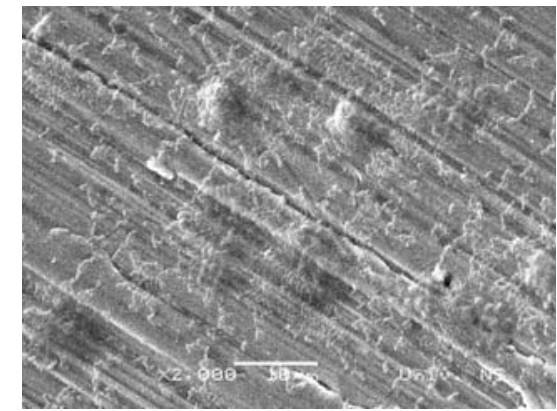

B. Strain 593 / 05 (x 2 000)

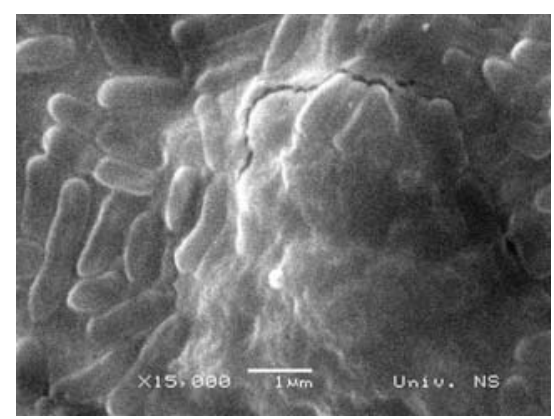

D. Strain 593 / 05 (x 15 000)

Figure 2. SEM images - three-dimensional cell aggregates of Listeria monocytogenes strains 1915/04 i $593 / 05$ on stainless steel after 7 days of incubation in TSB at $25^{\circ} \mathrm{C}$ 
Acta Veterinaria (Beograd), Vol. 59. No. 4, 423-435, 2009.

Milanov Dubravka et al.: Scanning electron microscopy of

Listeria monocytogenes biofilms on stainless steel surfaces

The strain L. monocytogenes 593/05 did not form a uniform distribution of cells across the entire steel surface, with uncovered regions clearly visible at lower magnification. Concurrently, the colonized areas reveal a "hilly landscape" characterized by large three-dimensional cell aggregates (Fig.2.B,C). The colonization rate in strains $L$. monocytogenes $\mathrm{F}$ and 154 was higher than that of the strain 593/05, revealing moderately elevated three-dimensional cell aggregates on the stainless steel surface (Fig.3. A-C).

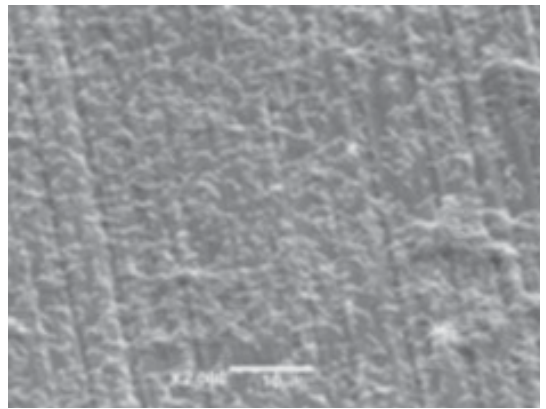

A. Strain $F(x 2000)$

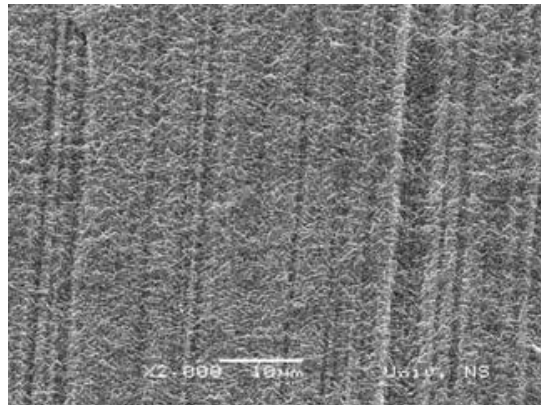

C. Strain 154 (x 2 000)

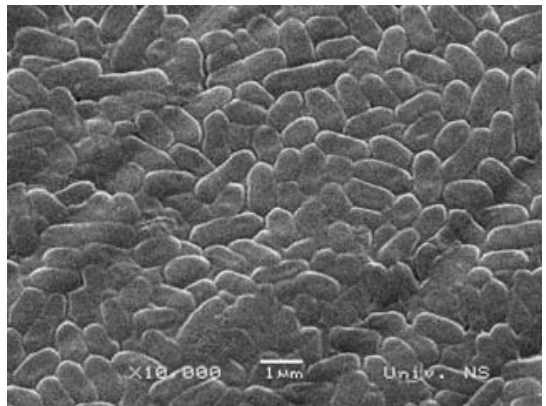

E. Strain 16 (x 10 000)

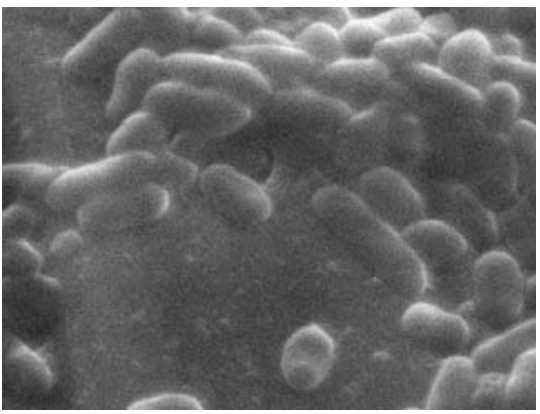

B. Strain F (x 20000$)$

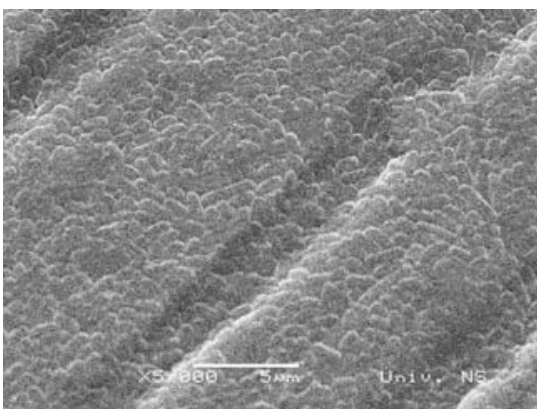

D. Strain 16 (x 5 000)

Figure 3. SEM images - biofilms of Listeria monocytogenes strains $\mathrm{F}, 154$ i 16 on stainless steel after 7 days of incubation in TSB at $25^{\circ} \mathrm{C}$ 
Strain 16 formed a uniform monolayer over the entire stainless steel surface without tending to form cell aggregates (Fig.3.D and E). The best ability of colonizing stainless steel surface and formation of characteristic cell aggregates was observed in strain $\mathrm{C}$, which completely covered the stainless steel surface, thus grooves on the surface that are characteristic for the finishing of this material are visible only as somewhat darker contours (Fig.4.A-C). Larger magnifications revealed two- or multiple- layer cell arrangement of the structures.

The obtained results strongly imply that there are substantial differences among Listeria monocytogenes strains with respect to their ability of colonizing the stainless steel surface and biofilm formation. In spite of quite a small number of isolates used in this testing this ability can not be attributed to the serological type of the organism. Chae and Schraft (2000) also could not establish the correlation between the serotype and origin of $L$. monocytogenes strains and their ability of adhering and forming biofilm on the stainless steel surface. Kalmokoff et al. (2001) established significant differences in the number of adhered cells among different strains of $L$. monocytogenes. However, the correlation between serotype or strain origin could not be confirmed.

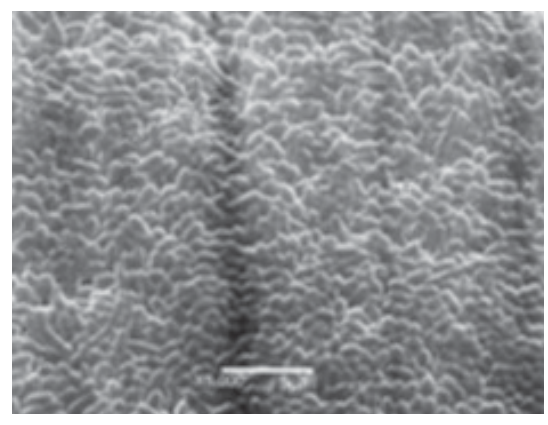

A. Strain C (magnification 5000 )

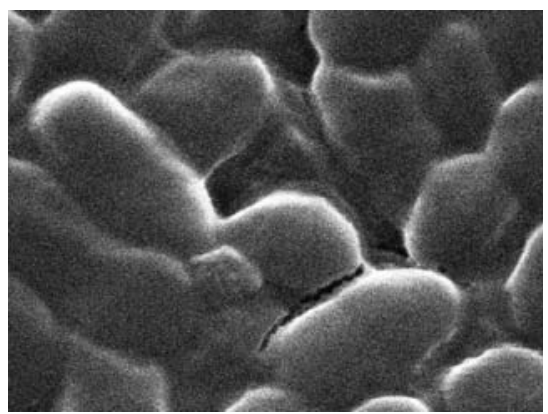

C. Strain C (magnification 45000 )

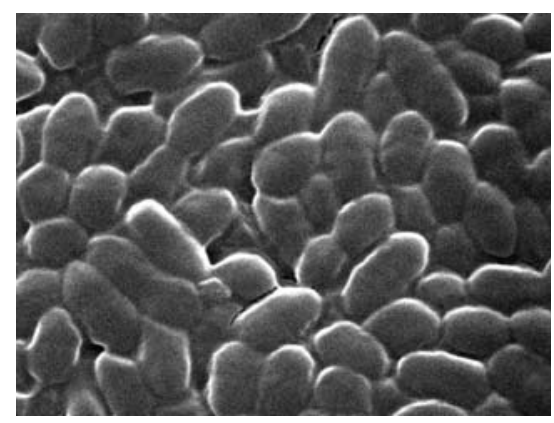

B. Strain C (magnification 20000 )

Figure 4. SEM images - biofilm of Listeria monocytogenes strain $\mathrm{C}$ on stainless steel after 7 days of incubation in TSB at $25^{\circ} \mathrm{C}$ 
The ability of biofilm formation in different $L$. monocytogenes strains is related to the individual features of the strain, its persistence (Norwood and Gilmour, 1999; Borucki et al., 2003; Lunden et al., 2000) and phylogenetic origin (Đorđević et al., 2002). Furthermore, experimental conditions such as incubation period and temperature, composition of nutritive medium and surface (substrate) characteristics, are of paramount importance. The control strain Scott $A$ used in the research of Kalmokoff et al. (2001) did not form biofilm on the stainless steel surface at room temperature for $72 \mathrm{~h}$ in the brain heart infusion broth. Experiment of Marsh et al. (2003) demonstrated that, in experimental conditions at $35^{\circ} \mathrm{C}$ in TSB, the same strain formed a biofilm of "honeycomb structure" with a clearly pronounced three-dimensional structure. The extracellular polymeric substance (EPS) observed in all biofilms of Listeria monocytogenes strains in this study were thread-like, binding one cell to another and to the surface. Chae and Schraft (2000) attribute the two-layer structure of the biofilm formed by two $L$. monocytogenes strains on glass surface to rather static conditions used in this experiment. According to the authors, the bacteria attached to the surface produce daughter cells that have only a loose association with EPS, because there are no constant external forces, such as the shear forces present in a continuous flow system, to keep cells attached more strongly and to promote the formation of common "mushroom-shaped" structures of microbial biofilms.

The described biofilm structures of Listeria monocytogenes distinctively differ from the commonly described "mushroom" biofilm structure, where bacterial cells (such as Staphylococcus spp.) are completely embedded in a thick, sticky extracellular substance. Marsh et al. (2003) report that Listeria monocytogenes biofilm architecture is probably more similar to a porous, sponge -like biofilm structure characteristic for Streptococcus mutans. Different types of EPS synthesized by bacteria or different signals involved in biofilm development could all contribute to these structural differences.

Chmielewski and Frank (2003) report that the biofilm appearance may vary from the single layer to the three-dimensional structure or take the form of aggregates such as flocks or granules.

In order to estimate the „span“ of the ability of $L$. monocytogenes to form a biofilm, in this experiment we used an isolate of Pseudomonas aeruginosa isolated from the milk of a cow with clinical mastitis. Pseudomonas species are well established good producers of biofilm and EPS. The preparation was made using a bacterial suspension of $P$. aeruginosa of the same density as for the tested strains of $L$. monocytogenes $\left(10^{7} \mathrm{cfu} / \mathrm{mL}\right)$, and the biofilm was prepared under the same conditions, with an incubation period of 7 days at $25^{\circ} \mathrm{C}$. Pseudomonas aeruginosa formed a dense three-dimensional biofilm with large amounts of ESP that completely covered the bacterial cells, thus they could not be detected by examining the upper coupon surface (Fig. 5.A). At the surface of the withered (condensed) matrix the cracks and pores were clearly obvious, which correspond to the appearance of water channels among bacterial microcolonies that transport nutrients, water and oxygen to the cells and excrete metabolic products. The cells of $P$. aeruginosa were detected only at the side parts of the coupons, where they were not covered by a biofilm matrix (Fig. 5.B). In comparison with the 

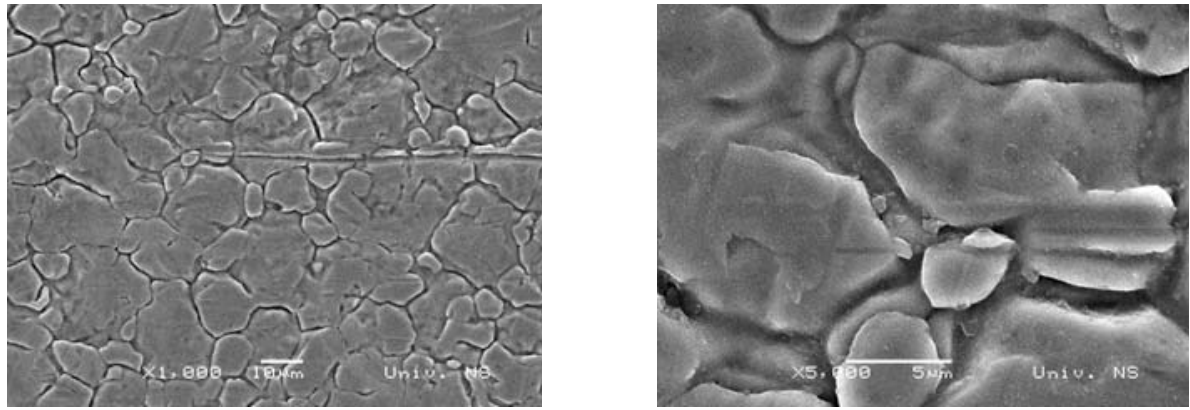

A. Appearance of the upper coupon surface with Pseudomonas aeruginosa biofilm (magnification 1000 and 5000)
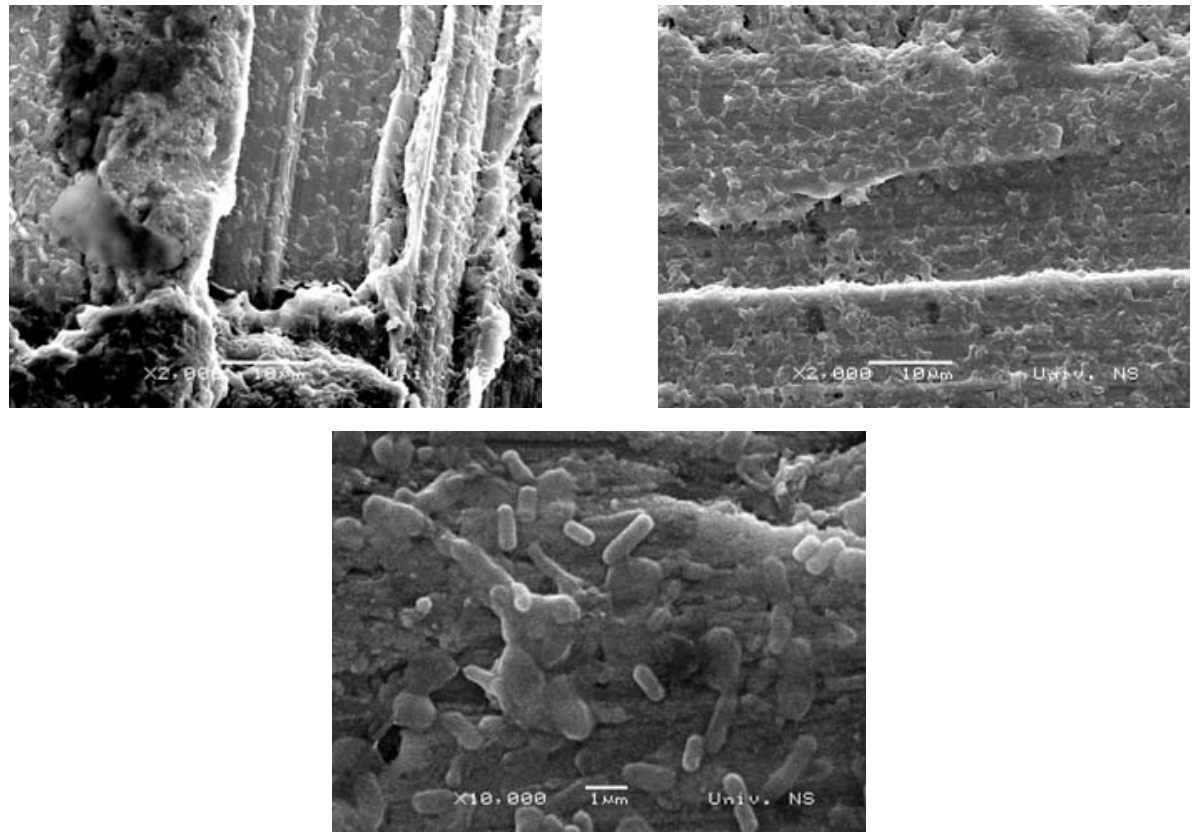

B. Appearance of the side coupon surface with Pseudomonas aeruginosa biofilm (magnification 2000 and 10 000)

Figure 5. SEM images - biofilm of strains Pseudomonas aeruginosa on stainless steel after 7 days of incubation in TSB at $25^{\circ} \mathrm{C}$

biofilm formed by $P$. aeruginosa, tested strains of $L$. monocytogenes exhibited a weak or moderate ability of biofilm formation, and particularly a weak ability of producing the extracellular polymeric substance. In strain 593/05 cells covered with withered mass that may correspond to the biofilm matrix (Fig. 2.D) are visible at a larger magnification. Prints of bacterial cells that were apparently embedded 
in this substance are clearly noticeable at a magnification of 30000 (Fig. 2.E). Such an appearance of the extracellular substance differs from the filamentous structures described by Kalmokoff et al. (2001), Borucki et al. (2003) and Marsh et al. (2003).

Considering the soft, highly hydrated structure of the biofilm the preparation of the substance for SEM requires a gradual dehydration procedure, because water is not compatible with the vacuum used for the electron ray. Dehydration results in substantial deformation of the biofilm matrix; however, excellent features of the electron microscopy resolution still make this technique highly applicable and important in biofilm research.

Further research is necessary to understand differences among strains of $L$. monocytogenes and their ability of biofilm formation. Knowledge obtained in this area will represent the first step in prevention of biofilm formation and elimination of persistent bacterial strains in the food processing environments (Harvey et al. 2007)

\section{ACKNOWLEDGEMENT:}

This investigation was supported by a grant from the Ministry of Science and Technological Development of the Republic of Serbia, Project No. 20115.

Address for correspondence:

Dr Dubravka Milanov

Scientific Veterinary Institute "Novi Sad"

Rumenački put 20, Novi Sad

Serbia

e-mail: dubravka@niv.ns.ac.yu

\section{REFERENCES}

1. Blackman IC, Frank J, 1996, Growth of Listeria monocytogenes as a biofilm on various food processing surfaces, J Food Prot, 59, 8, 827-31.

2. Borucki K Monica, Peppin JD, White D, Loge F, Call DR, 2003, Variation in biofilm formation among strains of Listeria monocytogenes, Appl Environ Microbiol, 69, 12, 7336-42.

3. Harvey J, Keenan KP, Gilmour A, 2007, Assessing biofilm formation by Listeria monocytogenes strains, Food Microbiol, 24, 380-92.

4. Chae MS, Schraft $H, 2000$, Comparative evaluation of adhesion and biofilm formation of different Listeria monocytogenes strains, Int J Food Microbiol, 62, 103-11.

5. Chavant P, Martinie B, Meylheuc T, Bellon-Fontaine M, Hebraud M, 2002, Listeria monocytogenes LO28: Surface Physicochemical Properties and Ability To Form Biofilms at Different Temperatures and Growth Phases, Appl Environ Microbiol, 68, 728-7.

6. Chmielewski RAN, Frank JF, 2003, Biofilm Formation and Control in Food Processing Facilities, Compr Rev Food Sci Food Safety, 2, 22-32.

7. Donlan RM, Costerton JW, 2002, Biofilms: Survival Mechanisms of Clinically Relevant Microorganisms, Clin Microbiol Rev, 15, 2, 167-93.

8. Đorđević D, Wiedmann M, McLandsborough A, 2002, Microtiter plate assay for assessment of Listeria monocytogenes biofilm formation, Appl Environ Microbiol, 68, 6, 2950-8.

9. Herald PJ, Zottola EA, 1988, Attachment of Listeria monocytogenes to stainless steel surfaces at various temperatures and $\mathrm{pH}$ values, J Food Sci, 53, 1549-52.

10. Hood S, Zottola E, 1997, Adherence to stainless steel by foodborne microorganisms during growth in model food systems, Int J Microbiol, 37, 145-53. 
11. Kalmokoff ML, Austin JW, Wan XD, Sanders G, Banerjee S, Farber JM, 2001, Adsorption, attachment and biofilm formation among isolates of Listeria monocytogenes using model conditions, J Appl Microbiol, 91, 725-34.

12. Lunden JM, Miettinen MK, Autio TJ, Korkeala HJ, 2000, Persistent Listeria monocytogenes strains show enhanced adherence to food contact surface after short contact time, J Food Prot, 63, 1204-7.

13. Mafu AA, Roy D, Goulet J, Magny P, 1990, Attachment of Listeria monocytogenes to stainless steel, glass, polypropylene and rubber surfaces after short contact time, J Food Prot, 53, 742-6.

14. Marsh EJ, Hongliang L, Wang H, 2003, A theree-tiered approach to differentiate Listeria monocytogenes biofilm-forming abilities, FEMS Microbiology Letters, 228, 2, 203-10.

15. Mead PS, Slutsker L, Dietz V, McCaig LF, Bresee JS, Shapiro C, Griffin PM, Tauxe RV, (1999) Foodrelated illness and death in the United States, Emerg Infect. Dis, 5, 607-25.

16. McLauchlin J, Mitchell RT, Smerdon WJ, Jewell K, 2004, Listeria monocytogenes and listeriosis: a review of hazard characterisation for use in microbiological risk assessment of foods, Int $J$ Food Microbiol, 92, 15-33.

17. Møretrø T, Langsrud S, 2004, Listeria monocytogenes: biofilm formation and persistence in foodprocessing environments, Biofilms, 1, 107-21.

18. Nelson J, 1990, Where are Listeria likely to be found in dairy plants? Dairy Food Environ San, 10, 6, 344-5.

19. Norwood DE, Gilmour A, 1999, Adherence of Listeria monocytogenes strains to stainless steel coupons, J Appl Microbiol, 86, 576-82.

20. Vogel BF, Huss HH, Ojeniyi B, Ahrens P, Gram L, 2001, Elucidation of Listeria monocytogenes contamination routes in cold-smoked salmon processing plants detected by DNA-based typing methods, Appl Environ Microbiol, 67, 2586-95.

\title{
SKENING ELEKTRONSKA MIKROSKOPIJA BIOFILMOVA SOJEVA LISTERIA MONOCYTOGENES NA NERĐAJUĆEM ČELIKU
}

\author{
MILANOV DUBRAVKA, AŠANIN RUŽICA, VIDIĆ BRANKA, KRNJAIĆ D, \\ PETROVIĆ JELENA i SAVIĆ SARA
}

\section{SADRŽAJ}

Listeria monocytogenes je uzročnik brojnih epidemija i sporadičnih slučajeva oboljenja ljudi, a hrana predstavlja glavni put prenošenja infekcije. Sirovine biljnog i animalnog porekla su jedan od mogućih izvora kontaminacije namirnica ovom bakterijom, što se posebno odnosi na prehrambene proizvode koji prolaze minimalni proces obrade. Međutim, poslednjih godina sve više se ističe značaj postprocesne kontaminacije, nastale kao rezultat kontakta prehrambenih proizvoda sa kontaminiranim površinama u pogonima prehrambene industrije, na kojima ova bakterija može u formi biofilma opstati mesecima, pa čak i godinama.

Uprkos skoro opšte prihvaćenom stavu da Listeria monocytogenes formira biofilm, malo je mikroskopskih dokaza koji to potvrđuju. U ovom radu ispitana je sposobnost formiranja biofilma kod 14 sojeva Listeria monocytogenes različitog porekla. Biofilmovi su formirani na površini nerđajućeg čelika za sedam dana 
Acta Veterinaria (Beograd), Vol. 59. No. 4, 423-435, 2009.

Milanov Dubravka et al.: Scanning electron microscopy of

Listeria monocytogenes biofilms on stainless steel surfaces

inkubacije u tripton soja bujonu sa dodatkom 0.6\% kvaščevog ekstrakta na temperaturi od $25^{\circ} \mathrm{C}$. Formirane strukture pregledane su skening elektronskom mikroskopijom.

Rezultati pregleda potvrđuju da među testiranim sojevima Listeria monocytogenes postoje značajne razlike u sposobnosti da formiraju biofilm pod korišćenim uslovima ispitivanja. Sedam od 14 testiranih sojeva Listeria monocytogenes nije formiralo biofilm, već su se njihove ćelije kao pojedinačne rasporedile po površini nerđajućeg čelika. Sojevi koji su procenjeni kao "biofilm producers" formirali su strukture različitog izgleda, od uniformnog, konfluentnog monosloja bakterijskih ćelija do pojedinačnih krupnih, trodimenzionalnih ćelijskih agregata. Svi ispitani sojevi su slabo produkovali ekstracelularnu polimeričnu supstanciju. 